DE IFGa Lata

Jurnal Ilmu Hukum

FAKULTAS HUKUM UMSU

\title{
PENGGUNAAN E-MONEY BERDASARKAN UNDANG-UNDANG NOMOR 7 TAHUN 2011 TENTANG MATA UANG
}

\author{
Roman Situngkir \\ Kantor Wilayah Kementerian Hukum dan HAM Provinsi Sumatera Utara \\ Jl. Putri Hijau, Medan - Sumatera Utara \\ Email: roman.situngkir@yahoo.co.id
}

\begin{abstract}
Abstrak
Penggunaan e-money baru-baru ini menimbulkan pro dan kontra setelah kebijakan pertanggungjawaban untuk penggunaan e-money untuk pembayaran di pintu tol. Ada pendapat bahwa pertanggungjawaban penggunaan e-money melanggar dan bertentangan dengan Undang-Undang Nomor 7 tahun 2011 tentang Mata Uang. Sehingga sangat menarik untuk melihat bagaimana sebenarnya keberadaan e-money berdasarkan Undang-Undang Nomor 7 tahun 2011 tentang Mata Uang. Dalam tulisan ini disimpulkan bahwa penggunaan e-money tidak bertentangan dengan Undang-Undang Nomor 7 tahun 2011 tentang Mata Uang. Karena e-money hanya diakui sebagai alat atau sistem pembayaran dan dosis tidak menggantikan mata uang resmi rupiah. Tetapi kemudian kewajiban untuk hanya menggunakan uang elektronik di pintu tol dan tidak menerima pembayaran tunai akan menjadi masalah lain. Tidak memberikan pilihan kepada masyarakat untuk memilih antara pembayaran tunai atau non tunai menggunakan e-money sebenarnya menyebabkan diskriminasi dan ketidakadilan dalam masyarakat. Haruskah pemerintah memberi orang pilihan untuk memilih antara pembayaran tunai atau menggunakan uang elektronik.
\end{abstract}

Kata Kunci: Uang, Elektronik, Pembayaran

\section{Abstract}

The recent use of e-money raises the pros and cons after the policy of liability for the use of e-money for payments at toll booths. There is an opinion that the liability for the use of e-money violates and contradicts Act No. 7 of 2011 about Currency. So it is interesting to see how the real existence of e-money based on Act No. 7 of 2011 about Currency. In this paper, it is concluded that the use of e-money is not contradictory to Act No. 7 of 2011 about Currency. Because e-money is only recognized as tool or payment system and dose not replace the official currency of rupiah. But then the obligation to use only e-money in toll booths and not to receive payment in cash would be another matter. Not giving the choice to the community to choose between cash or non-cash payment using e-money actually causes discrimination and injustice in society. Should the government give people the choice to choose between cash payments or using e-money.

Keywords: Money, Electronic, Payment

\section{PENDAHULUAN}

Di dalam perekonomian yang modern lalu lintas pertukaran barang dan jasa sudah sedemikian cepatnya sehingga memerlukan dukungan tersedianya sistem pembayaran yang handal yang memungkinkan dilakukannya pembayaran secara lebih cepat, efisien, aman dan handal (Bank Indonesia, 2006, h. 1). Secara umum, sistem pembayaran terdiri atas beberapa komponen berupa kebijakan, instrumen alat pembayaran, mekanisme kliring dan setelmen, kelembagaan, infrastruktur pendukung dan perangkat hukum. Beberapa contoh alat/instrumen pembayaran yang selama ini telah kita kenal adalah uang, kartu debit, kartu kredit, traveller's 
Jurnal Ilmu Hukum

FAKULTAS HUKUM UMSU
Penggunaan E-money Berdasarkan...(Roman Situngkir)

Volume 3 Nomor 1, Januari-Juni 2018, 52-59

DOI: $\underline{\text { https://doi.org/10.30596/dll.v3i1.3150 }}$

cheque, serta alat pembayaran elektronik seperti internet banking, RTGS, transfer kredit melalui kliring dan sebagainya (Bank Indonesia, 2006, h. 1).

Sesuai amanat Undang-undang Republik Indonesia Nomor 23 tahun 1999 tentang Bank Indonesia sebagaimana telah diubah dengan Undang-Undang Nomor 3 tahun 2004, tugas Bank Indonesia di bidang sistem pembayaran mencakup sistem pembayaran tunai dan non tunai.

Di dalam perkembangannya, sistem pembayaran non tunai sangat dipengaruhi oleh kemajuan perkembangan teknologi dan perubahan pola hidup masyarakat. Saat ini perkembangan instrumen pembayaran non tunai berjalan sangat pesat seiring dengan perkembangan teknologi sistem pembayaran yang pada akhir-akhir ini telah membawa dampak yang besar terhadap pihak-pihak yang terlibat dalam sistem pembayaran tersebut. Dengan dukungan teknologi yang semakin maju, masyarakat pengguna maupun penyedia jasa sistem pembayaran non tunai secara terus menerus mencari alternatif instrumen pembayaran non tunai yang lebih efisien dan aman. Selain itu, perubahan trend dan pola hidup masyarakat yang disertai peningkatan efisiensi pola hidup menuntut tersedianya sarana telekomunikasi dan transportasi yang demikian cepat sehingga hambatan jarak dan waktu dapat dikurangi. Perkembangan telekomunikasi dan transportasi ini juga memberikan pengaruh yang besar terhadap transaksi keuangan terutama terkait dengan cara antar pihak melakukan pembayaran. Kondisi terakhir menunjukan adanya interlinkage antar industri yakni telekomunikasi, transportasi dan jasa keuangan dimana diantara ketiga industri telah terjadi konvergensi yang mengintegrasikan kegiatan-kegiatan diantara industri tersebut. Sebagai contoh perusahaan penyedia jasa mobile telecomunication dalam rangka meningkatkan value added business telah menawarkan kepada pelanggannya fasilitas transaksi pembayaran menggunakan mobile phone. Demikian pula di bidang transportasi, untuk meningkatkan efisiensi dalam industri transportasi berbagai instrumen pembayaran telah digunakan sehingga pengguna transportasi dapat melakukan pembayaran secara lebih cepat, efisien dan aman. Konvergensi antar berbagai industri seperti jasa keuangan, telekomunikasi dan transportasi merupakan suatu awal yang akan menjadi pemicu munculnya instrumen pembayaran non tunai di masyarakat (Bank Indonesia, 2006, h. 1).

Penggunaan sistem pembayaran non-tunai menjadi viral ketika ada program yang mengharuskan semua pengguna jalan tol harus melakukan pembayaran dengan sistem nontunai menggunakan e-toll. Hal ini menjadi viral di sosial media ketika seorang pengguna media sosial mengunggah video ketika ditolak akan membayar tol dengan uang tunai dan harus membayar dengan e-toll. Video ini kemudian diikuti dengan video lain yang menunjukkan ketika pengguna jalan tol ingin menggunakan $e$-toll dan ternyata mesin $e$-toll rusak dan pengguna jalan tol diminta untuk melakukan pembayaran secara tunai dan kembali pengguna jalan tol menolak untuk membayar secara tunai.

Kedua video tersebut kemudian diiringi berbagai pendapat dari pengguna sosial media yang mempertanyakan bagaimana sebenarnya dasar penggunaan dari transaksi non-tunai atau e-money seperti e-toll dan sejenisnya jika kemudian dikaji berdasarkan Undang-Undang Nomor 7 Tahun 2011 tentang Mata Uang. Karena ada beberapa pendapat di sosial media yang menyatakan bahwa mewajibkan penggunaan pembayaran secara non-tunai menggunakan $e$ money seperti $e$-toll bertentangan dengan Undang-Undang Nomor 7 Tahun 2011 tentang Mata Uang. 
Jurnal Ilmu Hukum

FAKULTAS HUKUM UMSU

Bukan itu saja, setelah adanya pewajiban pembayaran tol menggunakan e-money, Forum Warga Jakarta (FAKTA) telah mendaftarkan uji materi Peraturan Bank Indonesia tentang uang elektronik ke Mahkamah Agung. Dengan alasan bahwa "pemaksaan" penggunaan uang elektronik telah menimbulkan keresahan dan pertanyaan di masyarakat terhadap keberadaan Undang-Undang tentang Mata Uang yang mengatur rupiah dalam bentuk kertas dan logam. Hal ini seperti mengamini pernyataan dari David Maruhum L. Tobing, seorang pengacara yang fokus pada isu perlindungan konsumen, yang mengatakan bahwa ketika konsumen tidak diberi pilihan untuk melakukan pembayaran tunai menggunakan uang kertas dan uang logam, artinya penolakan terhadap uang rupiah. Karena uang rupiah yang dimaksud dalam Undang-Undang Nomor 7 Tahun 2011 tentang Mata Uang adalah uang kertas dan uang logam.

Berdasarkan hal inilah, tulisan ini dibuat untuk melihat lebih lanjut bagaimana sebenarnya keberadaan penggunaan e-money jika dilihat berdasarkan Undang-Undang Nomor 7 Tahun 2011 tentang Mata Uang maka yang menjadi permasalahan dalam penulisan ini adalah, apakah penggunaan e-money bertentangan dengan Undang-Undang Nomor 7 Tahun 2011 tentang Mata Uang.

\section{METODE PENELITIAN}

Penulisan ini menggunakan metode penelitian hukum yuridis normatif (normatif research), yaitu penelitian hukum yang dilakukan dengan cara meneliti bahan pustaka atau data skunder (Seokanto dan Sri Muji, 2003, h. 15). Spesifikasi penelitian dalam penulisan ini berupa penelitian deskriptif analistis. Deskriptif adalah menunjukan komparasi atau hubungan seperangkat data dengan seperangkat data yang lain, dan maksudnya adalah untuk memberikan gambaran, menelaah, menjelaskan dan menganalisis (Soekanto, 1996, h. 63).

Sesuai jenis dan sifat penelitiannya, maka sumber data yang digunakan dalam penulisan ini adalah data skunder yang terdiri dari bahan hukum primer berupa Undang-Undang Nomor 7 Tahun 2011 tentang Mata Uang dan aturan hukum yang terkait dengan mata uang. Bahan hukum sekunder terdiri dari buku-buku, jurnal ilmiah, makalah dan artikel ilmiah yang dapat memberi penjelasan tentang bahan hukum primer. Bahan hukum tersier; berupa Kamus Besar Bahasa Indonesia (KBBI) dan lain sebagainya dalam menemukan defenisi dari istilah-istilah dalam membahas tentang penggunaan $e$-money bertentangan dengan Undang-Undang Nomor 7 Tahun 2011 tentang Mata Uang.

Prosedur yang digunakan untuk mengumpulkan data dalam penilitian ini berupa dokumentasi yaitu pedoman yang digunakan berupa catatan atau kutipan, penelusuran literatur hukum, buku-buku dan lainnya yang bertalian dengan identifikasi masalah dalam penilitian ini dengan cara offline maupun online. Analisa bahan hukum dilakukan dengan menggunakan metode analisa konten (centent analysis method) yang dilakukan dengan menguraikan materi peristiwa hukum atau produk hukum secara rinci guna memudahkan interpretasi dalam pembahasan (Marzuki, 2011, h. 171).

\section{PEMBAHASAN}

Penggunaan E-Money Bertentangan Dengan Undang-Undang Nomor 7 Tahun 2011 Tentang Mata Uang

\section{Sejarah Penggunaan $E$-Money di Indonesia}

Menurut ketentuan Pasal 1 angka 3 Peraturan Bank Indonesia Nomor 16/8/PBI/2014 tentang Perubahan atas Peraturan Bank Indonesia Nomor 11/12/PBI/2009 tentang Uang 
Jurnal Ilmu Hukum

FAKULTAS HUKUM UMSU
Penggunaan E-money Berdasarkan...(Roman Situngkir)

Volume 3 Nomor 1, Januari-Juni 2018, 52-59

DOI: $\underline{\text { https://doi.org/10.30596/dll.v3i1.3150 }}$

Elektronik disebutkan bahwa uang elektronik (electronic money) adalah alat pembayaran yang memenuhi unsur-unsur sebagai berikut:

1) diterbitkan atas dasar nilai uang yang disetor terlebih dahulu kepada penerbit;

2) nilai uang disimpan secara elektronik dalam suatu media server atau chip;

3) digunakan sebagai alat pembayaran kepada pedagang yang bukan merupakan penerbit uang elektronik tersebut; dan

4) nilai uang elektronik yang dikelola oleh penerbit bukan merupakan simpanan sebagaimana dimaksud dalam undang-undang yang mengatur mengenai perbankan.

Meskipun relatif masih dalam tahap perkembangan awal, e-money mempunyai potensi dalam menggeser peran uang tunai untuk pembayaran-pembayaran yang bersifat retail sebab transaksi retail tersebut dapat dilakukan dengan lebih mudah dan murah baik bagi konsumen maupun pedagang (merchant). Pengembangan e-money di berbagai negara telah melahirkan berbagai issue implikasi pengembangan e-money terhadap kebijakan Bank Sentral khususnya yang berkaitan dengan fungsi pengawasan sistem pembayaran dan efektifitas kebijakan moneter (Ni Nyoman Anita Candrawati, 2013, h. 9).

Bank Indonesia menerbitkan uang elektronik pertama kali di bulan April 2007. Selama kurang lebih satu setengah tahun sejak pertama terbit jumlah uang elektronik telah mencapai 430,000. Berbeda pada awal penerbitannya, uang elektronik saat ini tidak hanya diterbitkan dalam bentuk chip yang tertanam pada kartu atau media lainnya (chip based), namun juga telah diterbitkan dalam media lain yaitu suatu media yang saat digunakan untuk bertransaksi akan terkoneksi terlebih dulu dengan server penerbit (server based). Begitu pula dari sisi penggunaannya, hampir dari seluruh uang elektronik yang diterbitkan tidak lagi bersifat single purpose namun sudah multi purpose sehingga dapat diterima di banyak merchant yang berbeda (Ni Nyoman Anita Candrawati, 2013, h. 9).

Penggunaan uang elektronik di Indonesia cenderung mengalami peningkatan baik dari sisi jumlah uang elektronik beredar maupun volume transaksi. Berdasarkan data Bank Indonesia, sejak tahun 2007 hingga tahun 2015 tercatat 20 penerbit uang elektronik yang terdiri atas bank dan non bank. Sedangkan berdasarkan volume transaksi, pada tahun 2015 terhitung mulai dari Januari hingga Juni 2015, volume transaksi uang elektronik sebanyak 223.358.929 transaksi. Hal ini jauh jika dibandingkan dengan tahun pertamanya yaitu tahun 2007 (Lia Handayani, 2015, h. 1).

\section{Dampak Penggunaan E-Money}

Secara umum kebijakan e-money sebagai salah satu jenis dari model pembayaran non tunai telah memberikan beberapa dampak bagi beberapa sektor seperti pada perekonomian dan moneter, hal ini dapat terjadi karena kebijakan yang dikeluarkan Bank Indonesia ini menyangkut tentang sistem pembayaran dan transaksi keuangan yang digunakan masyarakat sehingga berdampak pada beberapa bidang ekonomi dan moneter. Dampak atau implikasi yang terjadi karena penerapan kebijakan sistem e-money terjadi di beberapa aspek hukum, teknis dan mekanisme operasionalnya (Arsita Ika Adiyanti, 2015, h. 23).

\section{Dampak E-money Terhadap Penerbit (Issuer)}

Penerbit atau issuer adalah pihak yang membuat dan menyediakan kartu e-money, penerbit e-money terdiri dari sektor perbankan dan non perbankan. Para penerbit tersebut telah sah dan legal untuk membuat e-money karena telah mengantongi izin dari Bank Indonesia. Penerbit yang telah disahkan oleh Bank Indonesia tersebut dapat menyediakan kartu $e$-money bagi masyarakat.

Dengan hadirnya e-money maka bertambah pula jenis fasilitas pembayaran non tunai yang disediakan perbankan, namun masyarakat masih belum tertarik dan masih kurang informasi mengenai penggunakan fasilitas e-money dan hal ini mengakibatkan tumbuhnya 
Jurnal Ilmu Hukum

FAKULTAS HUKUM UMSU

jumlah alat pembayaran menggunakan kartu atau APMK seperti kartu debit kartu kredit meningkat.

Bagi masyarakat, APMK (Alat Pembayaran Menggunakan Kartu) sendiri merupakan sebuah fasilitas yang dapat mempermudah proses transaksi seperti penarikan tunai, transfer dan pembayaran tagihan. APMK memberi manfaat efisiensi berupa penurunan biaya transaksi bagi konsumen dan produsen serta meningkatnya kepuasan masyarakat karena terpenuhinya kebutuhan akan alat pembayaran yang mudah dan praktis. Dengan adanya keberadaan dan penggunaan APMK seperti e-money tersebut dapat mengurangi biaya yang dikeluarkan masyarakat ketika memiliki uang baik untuk transaksi maupun berjaga-jaga.

Peningkatan konsumsi dan pertumbuhan ekonomi yang terjadi dari penggunaan $e$ money tersebut pada gilirannya berpotensi mendorong kembali permintaan masyarakat terhadap uang non tunai guna mempermudah dan mempercepat proses transaksi yang dilakukan. Bagi bank atau lembaga penerbit pembayaran non tunai, hal ini kembali berpotensi pendapatan dan keuntungan. Hal ini disebut sebagai dual effect atau dampak berganda dari penggunaan alat pembayaran non tunai. Dampak berganda dari penggunaan pembayaran non tunai kepada konsumen dan pengusaha tersebut pada gilirannya dapat mendorong pertumbuhan ekonomi.

\section{Dampak $E$-money Terhadap Pedagang atau Pengusaha (Merchant)}

Pengusaha atau merchant dalam sistem e-money ini adalah pengusaha atau pedagang yang menyediakan penggunakan fasilitas jasa pembayaran dengan e-money dalam transaksi pembayarannya. Pengusaha dalam hal ini berupaya menyiapkan hal ini untuk meningkatkan efektifitas dan efisiensi usahanya. Dari sisi pengusaha, peningkatan konsumsi yang diikuti dengan efisiensi biaya transaksi akan meningkatkan profit bagi pengusaha yang kemudian berpotensi untuk mendorong aktivitas usaha dan eskpansi usaha. Semakin efisien biaya transaksi yang diperoleh dari penggunaan alat pembayaran non tunai semakin besar potensi peningkatan output. Hal ini pada gilirannya mendorong peningkatan produksi di sektor riil yang dapat mendorong pertumbuhan ekonomi.

Secara teknis operasional, dengan menggunakan layanan e-money maka pengusaha dapat meminimalkan kesalahan yang terjadi dalam tiap transaksi dan dapat menghemat waktu yang diperlukan dalam sekali transaksi. Keuntungan yang didapatkan pengusaha dari tiap transaksi adalah keamanan dari uang yang ada dalam transaksi karena dana tersebut langsung dapat masuk ke rekening pengusaha tersebut.

Pengusaha mengharapkan dengan hadirnya e-money, efektifitas dan efisiensi usaha dapat terjadi. Efektifitas yang diharapkan adalah waktu untuk transaksi pembayaran dapat lebih cepat atau singkat karena dengan penggunaan kartu e-money pengusaha tidak perlu menyediakan uang kembalian dan tak perlu menghitung uang lagi. Para pengusaha tersebut dalam usahanya tidak perlu menyediakan uang tunai untuk melayani pembayaran dalam jumlah kecil atau mikro.

Sementara efisiensi yang terjadi dari penggunaan e-money bagi pengusaha adalah keamanan dalam tiap transaksi, dimana pengusaha tidak perlu khawatir akan adanya uang palsu dan saat transaksi selesai maka uang dari pembayaran akan masuk rekening pengusaha yang terhubung dengan transaksi.

\section{Dampak E-money Terhadap Pengguna Kartu E-money (Customer)}

Pengguna atau konsumen pengguna e-money dalam hal ini adalah orang yang menggunakan $e$-money dalam transaksi pembayarannya. Kemudahan yang diberikan oleh $e$ - 
Jurnal Ilmu Hukum

FAKULTAS HUKUM UMSU
Penggunaan E-money Berdasarkan...(Roman Situngkir)

Volume 3 Nomor 1, Januari-Juni 2018, 52-59

DOI: $\underline{\text { https://doi.org/10.30596/dll.v3i1.3150 }}$

money membuat para pengguna tidak perlu menyiapkan atau membawa dana tunai kemanapun saat pergi dan terhindar dari adanya uang palsu yang mungkin didapat jika melalukan transaksi secara tunai.

Penggunaan pembayaran non tunai dengan e-money selain meningkatkan pendapatan masyarakat melalui penurunan biaya transaksi dan penghematan waktu juga meningkatkan pendapatan masyarakat melalui pendapatan bunga yang diperoleh dari dana kas yang seharusnya dibawa dalam setiap kali bertransaksi namun ditempatkan di bank dalam bentuk tabungan. Dari sisi bank atau lembaga penerbit alat pembayaran non tunai, peningkatan penggunaan pembayaran non tunai merupakan sumber pendapatan berbasis biaya (fee base income) karena nasabah pengguna pembayaran non tunai akan dikenakan biaya administrasi setiap bulannya. Selain itu, pendapatan yang didapat dari biaya juga diperoleh dari biaya yang dikenakan untuk jenis transaksi tertentu misalnya untuk transfer atau pembayaran tagihan.

Adanya tambahan pendapatan yang diperoleh konsumen dari penggunaan $e$-money akan mendorong konsumsi dan permintaan masyarakat terhadap barang dan jasa yang pada gilirannya berpotensi mendorong aktivitas sektor riil. Di era sekarang ini orang enggan membawa uang dalam jumlah yang besar di dalam sakunya karena selain dipandang tidak aman juga dinilai tidak praktis. Besar kecilnya uang yang dibawa oleh masyarakat dalam melakukan transaksi pembayaran dapat menjadi pertimbangan sebagai kendala keefisiensian dalam pembayaran.

Kehadiran alat pembayaran non tunai seperti e-money yang berbentuk kartu menghilangkan kendala tersebut dan berpotensi untuk mendorong kenaikan tingkat konsumsi. Kemudahan dalam berbelanja yang diberikan bagi nasabah bank yang memiliki alat pembayaran non tunaiseperti ATM, kartu debet dan kartu kredit dapat mendorong kenaikan konsumsi dari nasabah tersebut. Hal ini dapat mendorong menigkatnya perputaran uang.

\section{E-Money Berdasarkan Undang-Undang Mata Uang}

Setelah adanya pendapat yang menyatakan bahwa penggunaan e-money bertentangan dengan Undang-Undang Nomor 7 Tahun 2011 tentang Mata Uang. Seperti yang dikemukakan oleh David Maruhum L. Tobing yang menyatakan bahwa penolakan pembayaran dengan mata uang rupiah kertas maupun logam patut diduga sebagai tindak pidana, sebagaimana diatur dalam Pasal 2 Ayat 2, Pasal 23 Ayat 1 dan Pasal 33 Ayat 2 Undang-Undang Nomor 7 Tahun 2011 tentang Mata Uang.

Pendapat ini kemudian dibantah dengan pendapat lain yang mengatakan bahwa penggunaan e-money tidak melanggar Undang-Undang Nomor 7 Tahun 2011 tentang Mata Uang. Salah satunya datang dari Institute for Development of Economics and Finance (Indef) mengaku tak sepakat jika Gerakan Nasional Non Tunai disebut bertentangan dengan Undang Undang Mata Uang. Uang elektronik atau e-money disebut masih termasuk dalam jenis uang yang sah di Republik Indonesia. Direktur Eksekutif Indef, Enny Sri Hartati mengatakan, di Indonesia ada dua jenis uang yaitu uang kartal dan uang giral. Uang kartal adalah uang kertas dan uang logam yang dipegang oleh masyarakat sehari-hari. Sementara itu, kalau uang giral adalah uang yang diakibatkan oleh proses aktivitas jasa-jasa perbankan. Lebih lanjut dia mengatakan bahwa $e$-money merupakan masuk kategori uang giral.

Pendapat yang sama juga dikemukakan oleh Deputi Gubernur Senior Bank Indonesia Mirza Adityaswara yang menegaskan bahwa uang elektronik sama sekali tidak bertentangan dengan Undang-Undang Nomor 7 Tahun 2011 tentang Mata Uang. Lebih lanjut dijelaskan bahwa dalam Undang-Undang Mata Uang disebutkan mata uang rupiah adalah mata uang yang sah yang wajib digunakan di Negara Kesatuan Republik Indonesia dan cakupan rupiah, 
Jurnal Ilmu Hukum

FAKULTAS HUKUM UMSU

berbentuk rupiah dalam bentuk fisik dan non-tunai.

Jika kemudian kita telusuri bunyi pasal yang dinyatakan sebagai dasar bahwa e-money bertentangan dengan Undang-Undang Mata Uang adalah sebagai berikut: Pasal 2 Ayat 2 Undang-Undang Nomor 7 Tahun 2011 tentang Mata Uang "Macam Rupiah terdiri atas Rupiah kertas dan Rupiah logam". Pasal 23 Ayat 1 Undang-Undang Nomor 7 Tahun 2011 tentang Mata Uang "Setiap orang dilarang menolak untuk menerima Rupiah yang penyerahannya dimaksudkan sebagai pembayaran atau untuk menyelesaikan kewajiban yang harus dipenuhi dengan Rupiah dan/atau untuk transaksi keuangan lainnya di Wilayah Negara Kesatuan Republik Indonesia, kecuali karena terdapat keraguan atas keaslian Rupiah."

Pasal 33 Ayat 2 Undang-Undang Nomor 7 Tahun 2011 tentang Mata Uang "Setiap orang dilarang menolak untuk menerima Rupiah yang penyerahannya dimaksudkan sebagai pembayaran atau untuk menyelesaikan kewajiban yang harus dipenuhi dengan Rupiah dan/atau untuk transaksi keuangan lainnya di Wilayah Negara Kesatuan Republik Indonesia, kecuali karena terdapat keraguan atas keaslian Rupiah sebagaimana dimaksud dalam Pasal 23 dipidana dengan pidana kurungan paling lama 1 (satu) tahun dan pidana denda paling banyak Rp. 200.000.000,00 (dua ratus juta rupiah)".

Jika kemudian ketentuan tersebut dengan pengertian dari e-money berdasarkan Peraturan Bank Indonesia Nomor 16/8/PBI/2014 tentang Perubahan atas Peraturan Bank Indonesia Nomor 11/12/PBI/2009 tentang Uang Elektronik yang menyatakan bahwa "uang elektronik (electronic money) adalah alat pembayaran, maka hal tersebut berarti bahwa $e$ money bukan merupakan jenis mata uang baru karena nominal atau nilai uang yang ada atau tertera di dalam e-money tetap dalam Rupiah. Selain itu, e-money hanyalah salah satu alat atau sistem untuk melakukan pembayaran.

\section{KESIMPULAN DAN SARAN Kesimpulan}

Berdasarkan beberapa argumen dan pendapat di atas dapat disimpulkan bahwa penggunaan e-money tidak bertentangan dengan Undang-Undang Nomor 7 Tahun 2011 tentang Mata Uang. Hal ini dikarenakan, e-money bukanlah jenis mata uang baru selain rupiah karena nilai atau nominal yang tertera pada e-money masih dalam nilai mata uang rupiah. Akan tetapi, penggunaan e-money menjadi viral dan dipermasalahkan adalah karena adanya pengharusan atau kewajiban penggunaan e-money dalam setiap transaksi di gardu tol dan tidak ada lagi gardu tol yang melayani pembayaran tunai. Hal ini tentu menimbulkan permasalahan baru. Memang, penggunaan e-money dianggap dapat memperlancar antrian di gardu tol dan mempercepat transaksi, akan tetapi pewajiban penggunaan e-money tentunya mengandung diskriminasi dan tidak sesuai dengan nilai keadilan di masyarakat. Seyogianya, pemerintah memberikan pilihan kepada masyarakat khususnya pengguna tol untuk memilih apakah ingin menggunakan pembayaran tunai atau non-tunai menggunakan $e$-money.

\section{Saran}

Meskipun penggunaan E-money tidak dilarang dan tidak bertentangan dengan peraturan perundang-undangan syogianya, pemerintah memberikan pilihan kepada masyarakat khususnya pengguna tol untuk memilih apakah ingin menggunakan pembayaran tunai atau non-tunai menggunakan $e$-money. 


\section{DAFTAR PUSTAKA}

Adiyanti, Arsita Ika. (2015). Pengaruh Pendapatan, Manfaaat, Kemudahan Penggunaan, Daya Tarik Promosi dan Kepercayaan terhadap Minat Menggunakan Layanan E-Money. Jurnal Ekonomi Universitas Brawijaya.

Bank Indonesia. (2006). Upaya Meningkatkan Penggunaan Alat Pembayaran Non-Tunai melalui Pengembangan E-Money, Bank Indonesia, Jakarta.

Candrawati, Ni Nyoman Anita. (2013). Perlindungan Hukum terhadap Pemegang Kartu EMoney sebagai Alat Pembayaran Transaksi Komersial. Jurnal Ekonomi Universitas Udayana

Handayani, Lia. (2015). Analisis Preferensi Penggunaan Uang Elektronik pada Kereta Api Commuter Jabodetabek. Jurnal Ilmiah Jurusan Ilmu Ekonomi Fakultas Ekonomi dan Bisnis Universitas Brawijaya, Malang

Marzuki, Peter Mahmud. (2011). Penelitian Hukum, Jakarta: Kencana Prenada Media Group.

Peraturan Bank Indonesia Nomor 16/8/PBI/2014 tentang Perubahan atas Peraturan Bank Indonesia Nomor 11/12/PBI/2009 tentang Uang Elektronik.

Seokanto, Sorejono., \& Sri, Muji. (1996). Pengantar Penelitian Hukum. Jakarta: UI Press.

Seokanto, Sorejono., \& Sri, Muji. (2003). Penelitian Hukum Normatif Suatu Tinjauan Singkat. Jakarta: Rajawali Pers.

Sofyan, Abidin Muhammad. (2018). Dampak Kebijakan E-Money di Indonesia sebagai Alat Sistem Pembayaran Baru. Universitas Negeri Surabaya

Undang-Undang Nomor 7 Tahun 2011 tentang Mata Uang. 